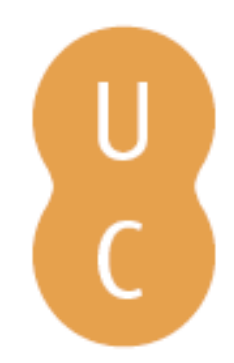

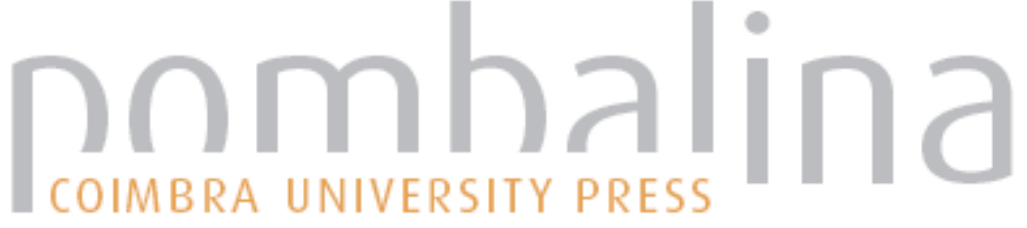

\section{Analysis of firebrand release on the spot fire mechanism}

Autor(es): $\quad$ Almeida, Miguel; Viegas, Domingos; Raposo, Jorge

Publicado por: Imprensa da Universidade de Coimbra

URL

persistente:

URI:http://hdl.handle.net/10316.2/34024

DOI:

DOI:http://dx.doi.org/10.14195/978-989-26-0884-6_6

Accessed : $\quad$ 26-Apr-2023 12:21:22

A navegação consulta e descarregamento dos títulos inseridos nas Bibliotecas Digitais UC Digitalis, UC Pombalina e UC Impactum, pressupõem a aceitação plena e sem reservas dos Termos e Condições de Uso destas Bibliotecas Digitais, disponíveis em https://digitalis.uc.pt/pt-pt/termos.

Conforme exposto nos referidos Termos e Condições de Uso, o descarregamento de títulos de acesso restrito requer uma licença válida de autorização devendo o utilizador aceder ao(s) documento(s) a partir de um endereço de IP da instituição detentora da supramencionada licença.

Ao utilizador é apenas permitido o descarregamento para uso pessoal, pelo que o emprego do(s) título(s) descarregado(s) para outro fim, designadamente comercial, carece de autorização do respetivo autor ou editor da obra.

Na medida em que todas as obras da UC Digitalis se encontram protegidas pelo Código do Direito de Autor e Direitos Conexos e demais legislação aplicável, toda a cópia, parcial ou total, deste documento, nos casos em que é legalmente admitida, deverá conter ou fazer-se acompanhar por este aviso. 


\section{ADVANCES IN}

Forest Fire

\section{RESEARCH}

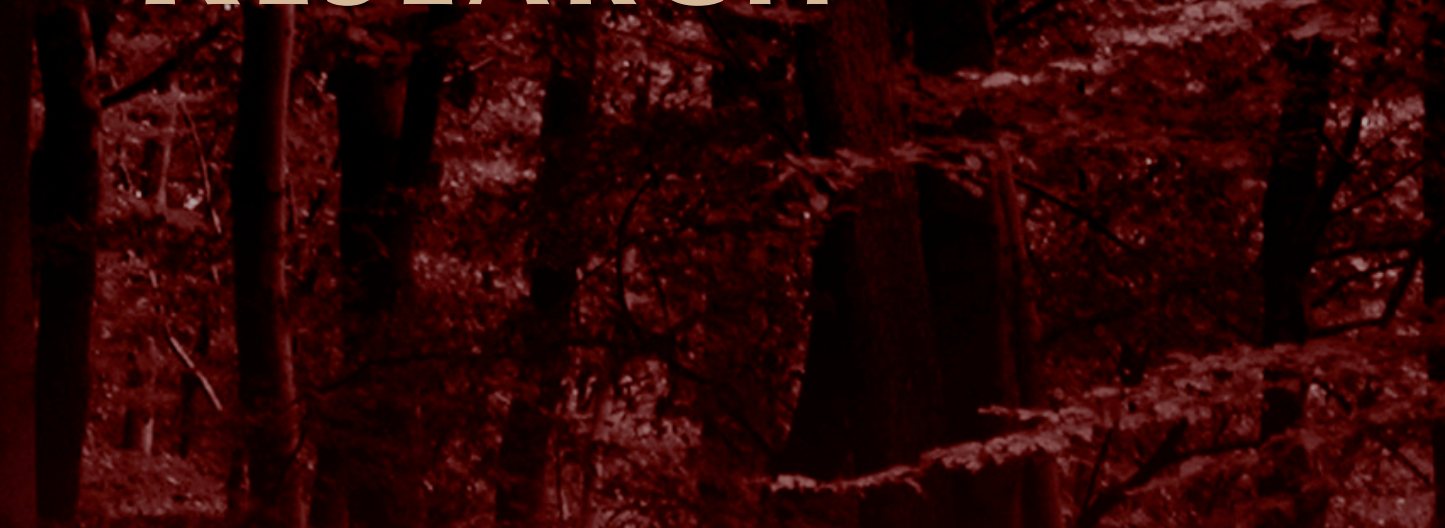

\section{DOMINGOS XAVIER VIEGAS}

\section{EDITOR}




\title{
Analysis of firebrand release on the spot fire mechanism
}

\author{
Miguel Almeida ${ }^{\mathrm{a}}$, Domingos Viegas ${ }^{\mathrm{a}}$, Jorge Raposo ${ }^{\mathrm{a}}$ \\ ${ }^{a}$ Centre for Forest Fire Research ADAI, Rua Pedro Hispano, 12, PT-3030-289 Coimbra, Portugal; \\ miguellmd@yahoo.com, xavier.viegas@dem.uc.pt,jorge.raposo@dem.uc.pt.
}

\begin{abstract}
Eucalyptus trees are among the most important sources of firebrands with potential to produce spot fires which are one of the most relevant manifestations of extreme fire behaviour. The mechanism of spot fires has several sequential phases starting in the release of a burning ember which is lofted and transported by the airflow, to land in a fuel bed causing a new ignition. In the present study, dedicated to the phase of firebrand release, an analysis of the firebrands released in a process of burning of eucalyptus trees is carried out.

Barks of eucalyptus trees have a great potential to produce firebrands during a forest fire. Sometimes these fuels are lay down on the ground or are attached to the trunk and to large branches of the canopy. In this study, the number and size distribution of firebrands released during the burning of these fuels for different scenarios are analysed. Three tests were made varying the location of the barks (suspended and lay down on a fuel bed) and the orientation of suspended barks (vertical and horizontal). An additional similar test was performed with a fuel bed composed of shrubs.

A particle image velocimetry system available in the Forest Fire Research Laboratory of ADAI was used to analyse the release of firebrands. Additionally, the convective up flow velocity and the temperature $2 \mathrm{~m}$ above the tree, as well as the weight loss decay were measured. The final results among the several parameters controlled are compared.
\end{abstract}

Keywords: forest fire, spot fire, spotting, firebrand, embers, eucalyptus, fire behaviour, extreme fire behaviour.

\section{Introduction and objectives}

The importance of the spotting mechanism in the propagation of forest fires is widely recognized by both the scientific community and the operational elements of civil protection. Its importance is not only due to the effect on increasing the rate of fire spread but also due to the ability to overcome firefighting barriers and fuel breaks, as well as the capacity to surprise and trap people. Additionally, for larger firebrands and particular environment conditions, the long distance spotting mechanism may originate new independent fires which can stress the firefighting system.

For several years ADAI has been studying the spot fires mechanism splitting it in five main stages: (1) release of firebrands, (2) lofting of firebrands in the convection column, (3) downwind transport of the firebrand, (4) landing of the firebrand and possibility of ignition, and (5) interaction between the spot fire and original fire front. This study is focused on the release of firebrands resulting from the burning of eucalyptus trees, specifically the burning of the eucalyptus trees barks. The analysis was made using a particle image velocimetry (PIV) system.

There are several models related to forest fire however the major part is related to the aerodynamic lifting and downwind transport (e.g. Albini, 1979, 1981, 1983a, 1983b; Sardoy et al., 2007) and some are related to the probability of ignition after the firebrand's landing (e.g. Viegas et al., 2012). There are many models (e.g. Ellis, 2000) predicting the spotting mechanism for individual particles, or a set of particles with similar characteristics released in the same location. The major limitation of these models is the understanding of how and where the firebrands are released and what physical properties these firebrands have.

Release of firebrands is actually poorly understood. The use of PIV in this context may be of great useful however it is currently in a very early stage. Several authors have used the PIV technique in the context of fires specifically to determine the flame and the convective flow characteristics (e.g. 
Morandini et al., 2012; Horváth et al., 2012) however those application were not in the context of spot fires. Hosseini et al. (2010) made a study reporting the characteristics of particle size distributions with focus on chaparral. Manzello et al. (2007) made a series of real-scale laboratory fire experiments to determine the size and mass distribution of firebrands generated from 2.6 to $5.2 \mathrm{~m}$ high Douglas-fir (Pseudotsuga menziesii) trees using an array of pans filled with water to collect the firebrands generated from the burning trees.

Eucalyptus trees are among the main sources of firebrands with potential to cause a spot fire (McArthur, 1967). Barks of the eucalyptus trees (Eucalyptus globulus Labill.) were assumed in this study as being one of the most important components to produce firebrands. Normally the barks can be found lay down on the ground or may be attached to the trunk or to large branches of the tree. The barks attached to the trunk show an orientation predominantly vertical. The barks attached to the branches show an orientation with a greater horizontal component.

Several burning tests were carried out for three different scenarios: 1) barks lay down on a fuel bed, 2) barks suspended in a tree predominantly with vertical orientation, and 3) barks suspended in a tree mainly in the horizontal position. It is expected a faster and more intense combustion of the suspended barks and specifically the vertical barks (Almeida et al., 2011). Higher intensity leads to a faster and more effective burning of the barks however it increases the up flow convective velocity intensifying the release of firebrands. On the other side, the horizontal orientation of the barks have a larger drag coefficient value (Almeida et al., 2010) facilitating the uplift of the firebrands.

To sustain the combustion and to increase the fire intensity, a fuel bed of shrubs was used. To understand the effect of the shrubs in the release of firebrands, a fourth test with a single fuel bed of shrubs, without barks, was carried out.

The numerical and size distribution of the firebrands released during the burning was determined using a PIV system. In parallel other parameters like weight loss decay, temperature and vertical convective flow at $2 \mathrm{~m}$ high were measured. A comparative analysis of the results was performed.

\section{Experimental study}

All the experiments following described were carried out in the Forest Fires Research Laboratory of ADAI (Association for the Development of Industrial Aerodynamics), in Lousã - Portugal.

Two different types of fuels were used in the experiments, namely eucalyptus barks (Eucalyptus globulus Labill.) and a mix of shrubs composed by heather (Calunna Vulgaris) and carquesia (Pterospartium tridentatum). The barks were detached randomly from the trunk and the large branches of the trees. The shrubs were cut using a brush cutter. All the fuels were collected in typical summer days and were stored inside the laboratory in controlled conditions of $T \approx 25^{\circ} \mathrm{C}$ and $R H \approx 40 \%$.

As previously mentioned, four burning tests were carried out using shrubs (T1) or shrubs and barks (T2, T3 and T4). Table 1 resumes the experimental conditions of each test. In $T 1$ the shrubs were lay down on the combustion table (Figure 1a). The fuel bed had the shape of a cone with a base of area of $0.81 \mathrm{~m}^{2}$ and $0.4 \mathrm{~m}$ high. This "basic" fuel bed of shrubs was common to all tests. In $T 2$ the barks were lay down on the shrubs to cover the upper surface (Figure 1b). In T3 (Figure 1c) and T4 (Figure 1d) the barks were suspended in a tree skeleton only with thickest branches. It was assumed that tree skeletons used do not burn to loose significant weight nor to produce firebrands. In T3 barks were suspended mainly with vertical orientation and in $T 4$ a predominant horizontal orientation of the barks was forced. The environmental laboratorial conditions (temperature $T$ and relative humidity $R H$ ), the fuels moisture content $(F M C)$, the initial fuel weight $\left(m_{0}\right)$, the tree skeleton height $(H)$ and diameter $(\varnothing)$ and the distance $(\Delta H)$ from the surface fuels and the tree canopy were also measured before the burning. The fuels were roughly totally consumed during the test. 
Table 1. Main data of the experimental conditions.

\begin{tabular}{|c|c|c|}
\hline REFERENCE & INITIAL CONDITIONS & FUELS CHARACTERISTICS \\
\hline $\mathrm{T} 1$ & $\begin{array}{l}\text { Fuel: shrubs } \\
\text { Temperature }\left({ }^{\circ} \mathrm{C}\right): 29.8 \\
\text { Relative humidity }(\%): 48\end{array}$ & 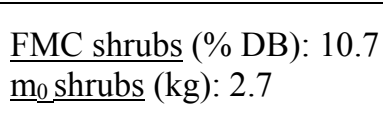 \\
\hline $\mathrm{T} 2$ & $\begin{array}{l}\text { Fuel: Barks and shrubs lay down } \\
\text { on the fuel bed } \\
\text { Temperature }\left({ }^{\circ} \mathrm{C}\right): 25.5 \\
\text { Relative humidity }(\%): 31 \\
\end{array}$ & $\begin{array}{l}\text { FMC barks (\% DB): } 14.1 \\
\text { FMC shrubs (\% DB): } 12.8 \\
\underline{\mathrm{m}}_{0} \text { barks }(\mathrm{kg}): 1.94 \\
\underline{\underline{\mathrm{m}}}_{0} \text { shrubs }(\mathrm{kg}): 2.8\end{array}$ \\
\hline $\mathrm{T} 3$ & $\begin{array}{l}\text { Fuel: Barks suspended with } \\
\text { vertical orientation } \\
\text { Temperature }\left({ }^{\circ} \mathrm{C}\right): 26.7 \\
\text { Relative humidity }(\%): 60\end{array}$ & 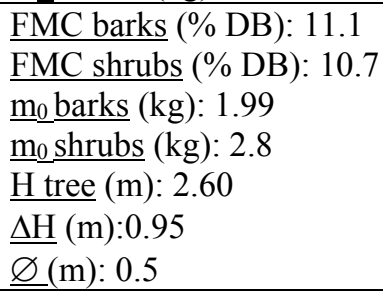 \\
\hline $\mathrm{T} 4$ & $\begin{array}{l}\text { Fuel: Barks suspended in } \\
\text { horizontal orientation } \\
\text { Temperature }\left({ }^{\circ} \mathrm{C}\right): 30.1 \\
\text { Relative humidity }(\%): 47\end{array}$ & 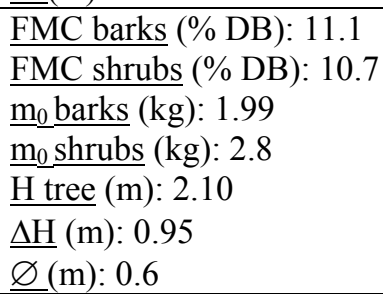 \\
\hline
\end{tabular}

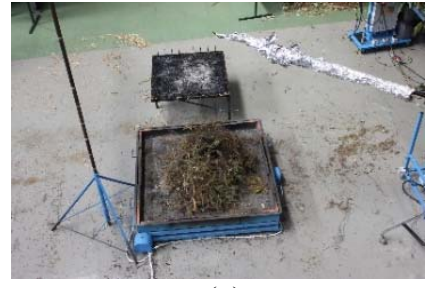

(a)

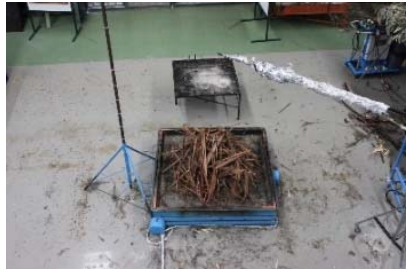

(b)

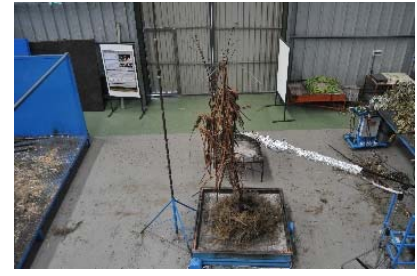

(c)

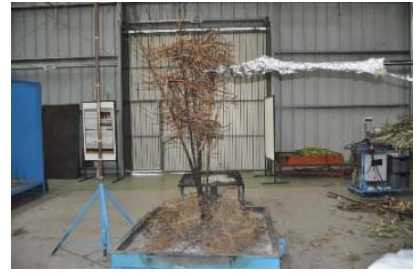

(d)

Figure 1. Images of the four burning tests carried out: a) T1, b) T2, c) T3 and d) T4.

The ignition was produced using a woollen yarn lying on the perimeter of the shrub fuel bed. The acquisition of weight, temperature and up flow velocity was initiated at the same time of the ignition. The PIV images started being captured when the total weight of the fuel bed was reduced to $88 \%$ of the initial value. By total weight of the fuel bed we understand the weight of all the elements over the table which, for example, in T4 are the shrubs, the barks and the tree skeleton.

The fuel bed was set up on a balance (precision: $0.01 \mathrm{~kg}$ ) allowing the measurement of the weight loss decay during the burning. The temperature and the vertical flow velocity at $2 \mathrm{~m}$ high in the central axis of the smoke plume were controlled throughout the experiment using a thermocouple and a Pitot tube, respectively.

The number and dimensions of the firebrands released were acquired from a PIV system. The PIV system is composed of a camera linked to a computer that store the images. The camera was placed in an elevated position in order to have a horizontal axis of image capture video. Figure 2 shows a representation of the experimental apparatus. 


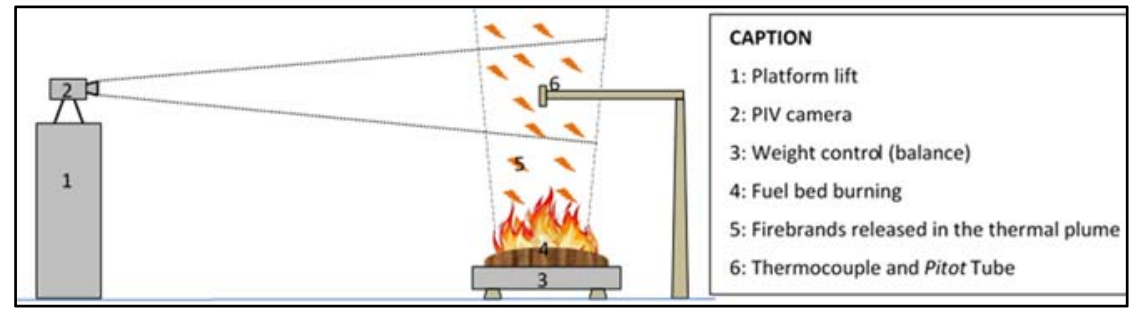

Figure 2. Experimental apparatus.

The images were captured for $25 \mathrm{~s}$. As previously mentioned, the image acquisition started when the total weight of the fuels was reduced to $88 \%$ of the initial value as it was observed to be the moment when the burning blows up to a higher intensity and more firebrands are released. The area covered by each PIV image is a rectangle of $2320 \mathrm{~mm}$ width and $1728 \mathrm{~mm}$ height with the centre $3.5 \mathrm{~m}$ above the centre of the fuel bed. Particle were identified and characterized using the Dynamic Studio software of Dantec. After the preliminary identification of the particles of interest (Figure 3) only particles with equivalent diameter larger than $1.7 \mathrm{~mm}$ were considered as interesting for this study. Besides the major part of the firebrands released has an equivalent diameter lower than $1.7 \mathrm{~mm}$, we considered that very small particles with lower calorific values do not represent an effective threat to cause a spot fire when lofted in the experimental conditions of burning.

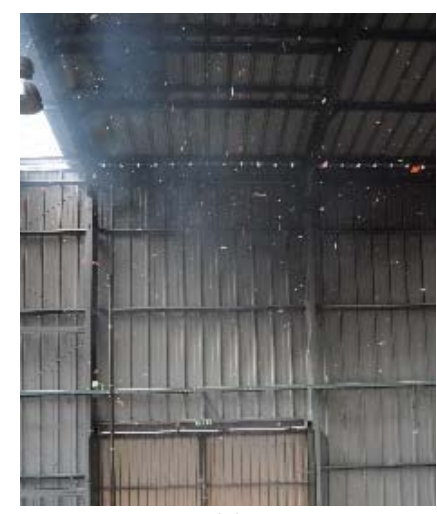

(a)

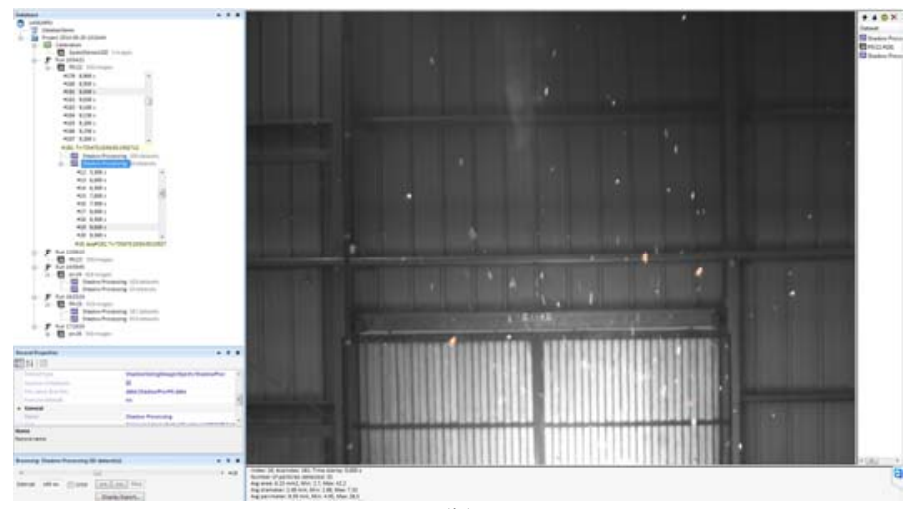

(b)

Figure 3. Images of the firebrand release (test T1): a) photographic image, and b) PIV image after the preliminary identification of the firebrands (red lines involving the particles).

\section{Results and discussion}

The weight loss decay was analysed taking into consideration that initial total weight was different among the four tests. Therefore a relative weight loss decay $\dot{m}$ was determined using Equation 1 where $m_{t}$ is the mass of the fuel bed at any instant $t$ and $m_{0}$ is the initial mass of the fuel bed. The weight of the tree skeleton was reduced as this element did not participated in the combustion. In Figure 4 the variation of $\dot{m}$ during the experiments is represented. Following Almeida (2011), the weight loss decay can be fitted with an exponential law as shown in Eqn. 2 where $k$ is the weight loss coefficient represented in Table 2. As can be seen the weight loss decay for T3 and T4 is quite similar and were the tests with faster decrease of fuel relative weight. On the other side, test $T 2$ burned slowly essentially due to the coverture of the shrubs fuel bed by the barks that muffled the flames delaying the burning. The values for Test $T 1$ were below those verified for T3 and T4 because the absence of barks that have a good combustibility rate.

$$
\dot{m}=\frac{m_{t}}{m_{0}} \quad \text { [Eqn. 1] }
$$




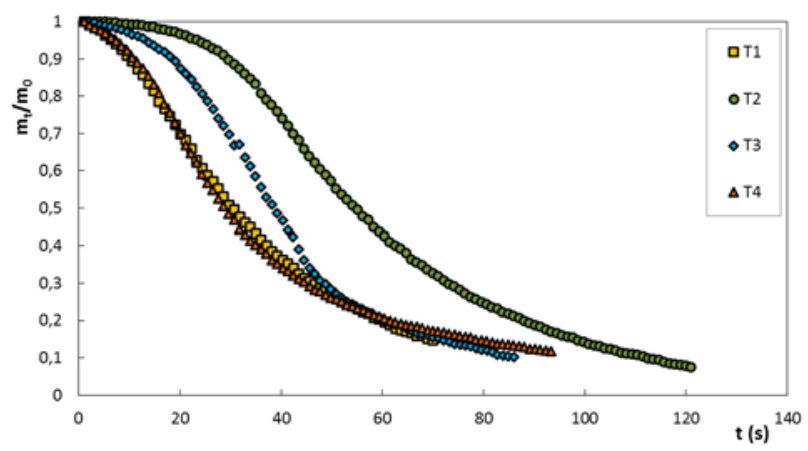

(a)

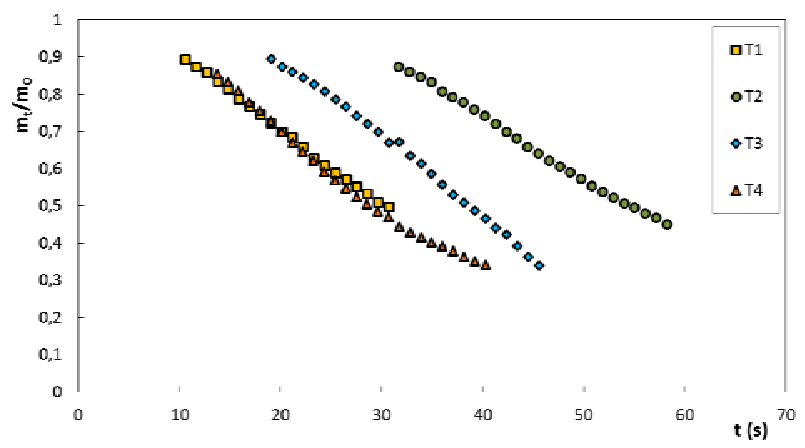

(b)

Figure 4. Relative weight loss decay (Eqn. 1) measured throughout the burning tests: a) all the values of the tests and (b) the values related to the period when the PIV images were captured.

$$
m=m_{0} \times \exp (-k \times t) \quad[\text { Eqn. 2] }
$$

Table 2. Values of the weight loss decay $k$.

\begin{tabular}{|c|c|c|c|c|}
\hline REFERENCE & $\mathrm{T} 1$ & $\mathrm{~T} 2$ & $\mathrm{~T} 3$ & $\mathrm{~T} 4$ \\
\hline $\mathrm{k}\left(\mathrm{s}^{-1}\right)$ & 0.0299 & 0.0256 & 0.0354 & 0.0360 \\
\hline
\end{tabular}

The combustion rate during the range of time for what the PIV images were captures that is the period of interest for this study was very constant. The fitting of a linear equation of the values represented in Figure $4 \mathrm{~b}$ drives to correlation coefficients $r^{2}$ larger than 0.98 . Therefore the determination of average values for the other parameters (temperature, up flow velocity and number and area of firebrands) is reasonable.

The measured temperature $T$ and the determined up flow velocity $V$ values are represented in Figure 5. In Figure 5a, the values of $T$ and $V$ during the complete burning in test $T 4$ is given for exemplification. Figure $5 \mathrm{~b}$ represents the values of $V$ for tests $T 1, T 3$ and $T 4$ during the time of the PIV images acquisition. The respective files of $T 2$ were corrupted and therefore the results for this test are not presented. Table 3 resumes the average values of $T_{a v}$ and $V_{a v}$ for each test. It is possible to observe that values of temperature and up flow velocity are lower for $T 1$ than for $T 3$ and $T 4$, which are very similar. The lower intensity of $T 1$ verified and described during the analysis of $k$ can explain these results. Additionally, the lower distance between the suspended barks and the Pitot tube, in T3 and T4, when compared to the larger distance between the shrubs fuel bed and the Pitot tube in T1, can also explain that discrepancy of $T_{a v}$ and $V_{a v}$ among the tests.

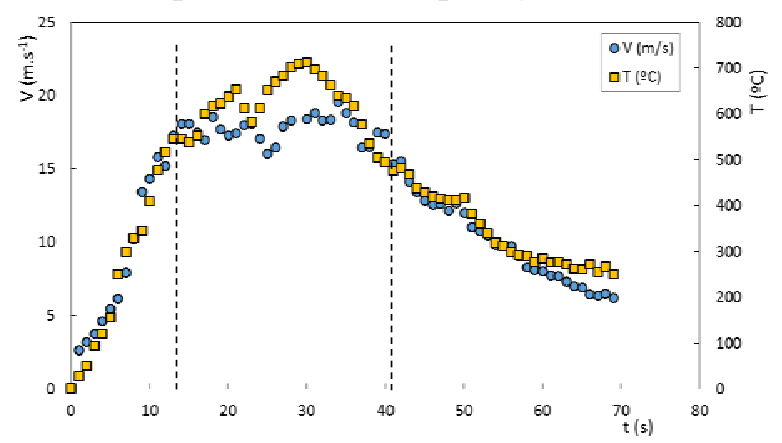

(a)

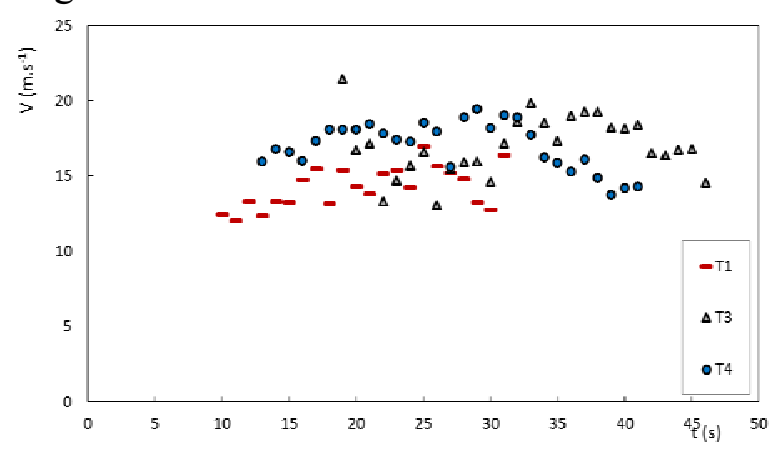

(b)

Figure 5. Example of the values of temperature (T) and convective up flow velocity (V) measured throughout a burning test (T4). Vertical dotted lines correspond to the time period when the PIV images were captured. 
Table 3. Values of average temperature $T_{a v}$ and average up flow velocity $V_{a v}$.

\begin{tabular}{|c|c|c|c|c|}
\hline REFERENCE & T1 & T2 & T3 & T4 \\
\hline $\mathrm{T}_{\mathrm{av}}\left({ }^{\circ} \mathrm{C}\right)$ & 541.5 & $\mathrm{~N} / \mathrm{D}$ & 607.7 & 613.8 \\
\hline $\mathrm{V}_{\mathrm{av}}\left(\mathrm{m} . \mathrm{s}^{-1}\right)$ & 14.3 & $\mathrm{~N} / \mathrm{D}$ & 17.0 & 17.0 \\
\hline
\end{tabular}

In Figure 6 the total number of particles released and captured by the PIV system for each test is shown. It is possible to see that in general terms the fuel bed composition producing more firebrands was that of test $T 1$ (shrubs) with an average value of 113 particles per image (Table 4) during the analysed range of time. Test $T 2$, with barks and approximately the same load of shrubs than $T 1$, produces an average value of 69 particles.image ${ }^{-1}$. The barks work like a cover of the shrubs do not allowing the lofting of the firebrands. However, when this "cover" is passed through by the firebrands they can be lofted. The number of particles released during T3 was even lower and $N_{a v}$ for T4 was slightly above of $T 2$. We could observe in laboratory that the tree skeleton with the barks suspended work as an obstacle for the lofting of the firebrands released from the shrub fuel bed. As consequence these firebrands were not lofted to the higher level were the PIV camera was pointed. When the barks start burning more intensively the number of firebrands increased assuming being counted 171 particles for T4. This was the larger value for all the tests. Surprisingly this increase of intensity was not traduced in an increase of the up flow velocity nor the weight loss decay. The superior number of particles verified in T4 when compared with T3 is due the higher drag coefficient of the horizontal barks facilitating the lofting of the particles and the breakage of the burning bark in small particles.

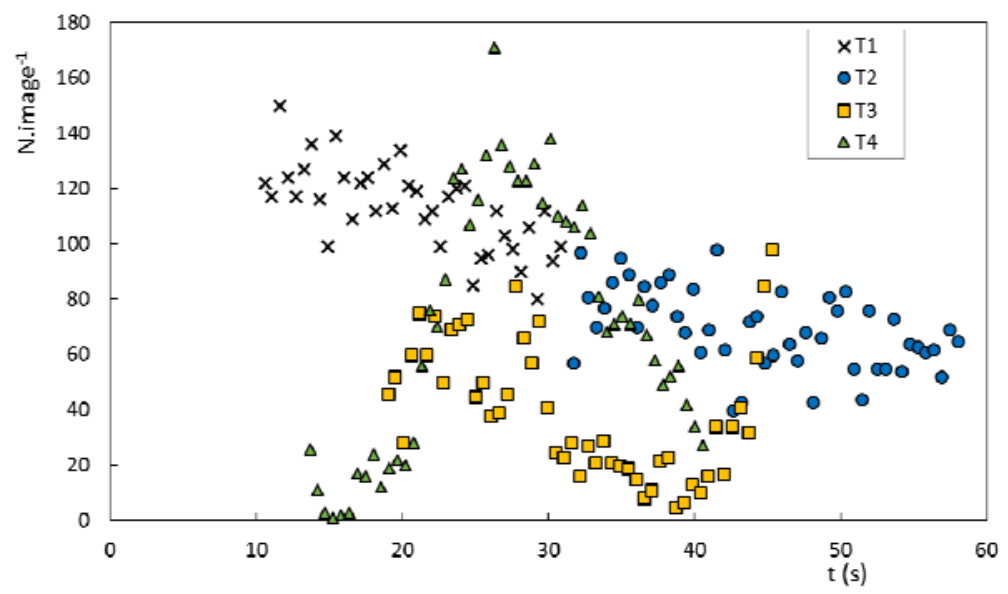

Figure 6. Total number of firebrands released during the burning captured by the PIV camera.

Table 4. Values of average number of particles per PIV image.

\begin{tabular}{|c|c|c|c|c|}
\hline REFERENCE & $\mathrm{T} 1$ & $\mathrm{~T} 2$ & $\mathrm{~T} 3$ & $\mathrm{~T} 4$ \\
\hline $\mathrm{N}_{\mathrm{av}}$ & 113 & 69 & 40 & 71 \\
\hline
\end{tabular}

In Figure 7the distribution of the released particles by dimensional classes is represented for each test. The area of classes in $\mathrm{mm}^{2}$ correspond to the projected area of the particles captured by the PIV system. Test $T 1$ only with shrubs as burning fuel has the larger number of firebrands, as it was mentioned before, however around $77 \%$ of the particles have a projected area below $100 \mathrm{~mm}^{2}$. Test $T 2$ was that one with less particles released however more than $41 \%$ of these particles have an area larger than $1000 \mathrm{~mm}^{2}$. The small particles released during the burning of shrubs were not lofted due to the barks cover however the burning of the barks produced firebrands with larger dimensions. Like for T1 and 
T2, particles below $100 \mathrm{~mm}^{2}$ were the most represented in $T 3$ and $T 4$. While $T 1$ and $T 2$ roughly did not produced particles in the class $\left[100 ; 500\left[\mathrm{~mm}^{2}\right.\right.$, tests $T 3$ and $T 4$ with barks suspended, originate several particles in this range of area. On the other side these two tests produced less firebrands of larger dimensions. The more intensive burning verified in T3 and T4 can explain this achievement.

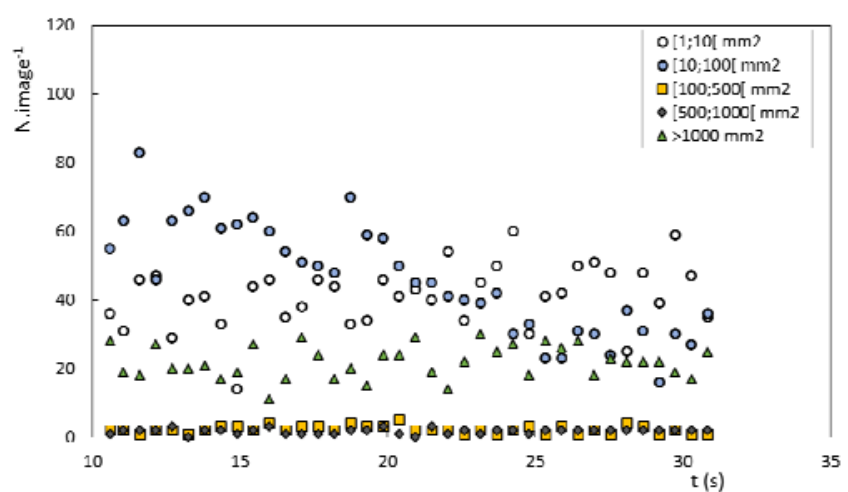

(a)

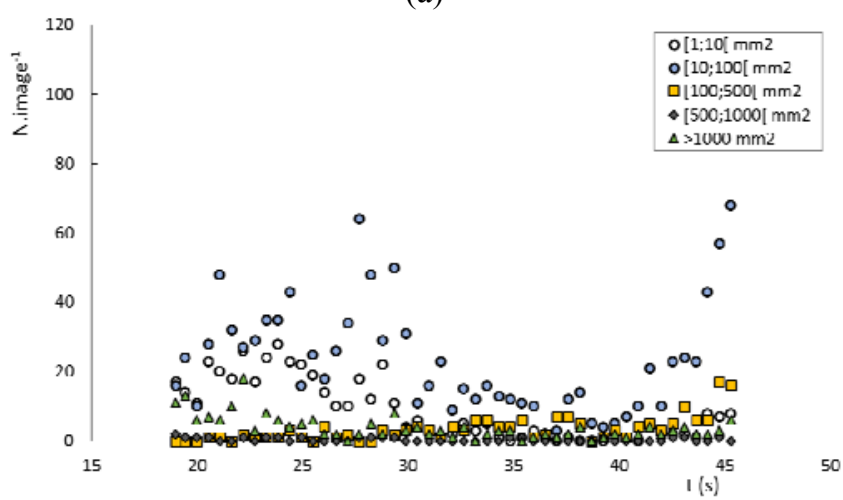

(c)

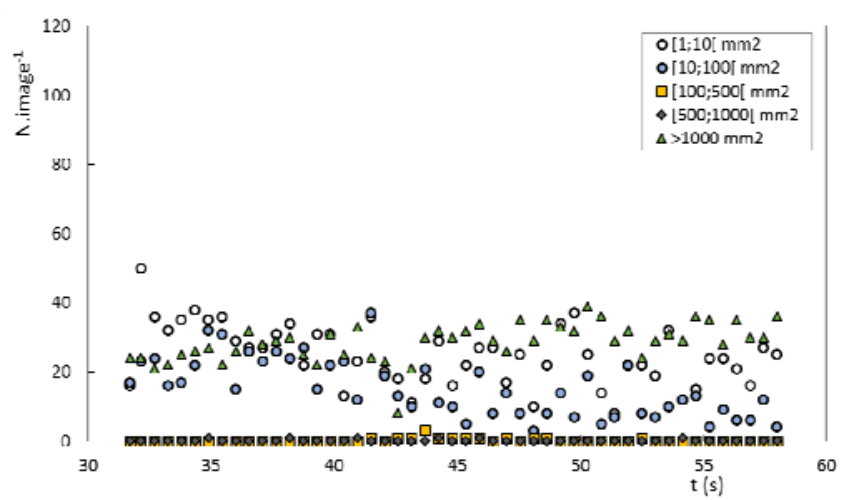

(b)
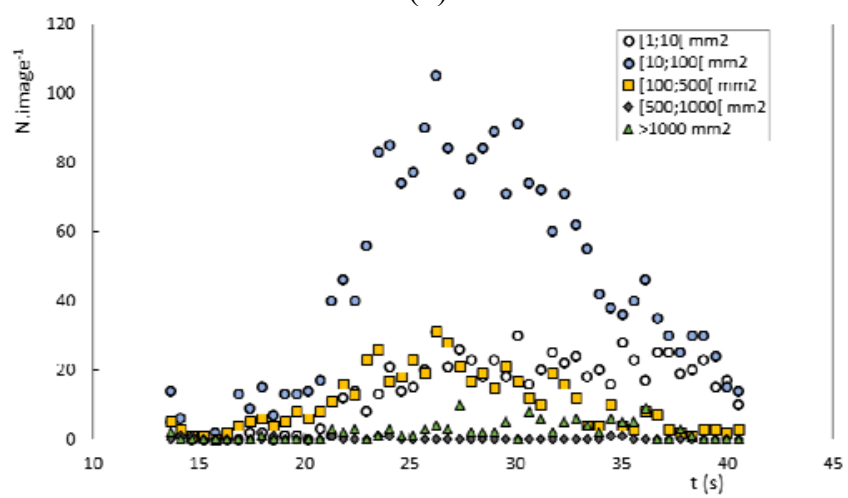

(d)

Figure 7. Numeric distribution of firebrands released during the burning captured by the PIV camera for T1 (a), T2 (b), T3 (c), and T4 (d).

The analysis of the projected areas was carried out as well as showed in Figure 8 and Figure 9. If we consider that projected areas are proportionally related to the volume of the particles and consequently to the mass, it can be concluded that tests $T 1$ and $T 2$ produced a larger mass of firebrands. It can be seen in Figure 9 that particles larger than $1000 \mathrm{~mm}^{2}$ contribute mainly for this result. The more intense tests T3 and T4 produced a lower mass of particles as a great amount of fuel is converted in smoke with particles below $1 \mathrm{~mm}^{2}$. Besides $T 4$ produced a larger number of particles than $T 3$, the total area of the particles per image was similar due to the different distribution per area classes. 


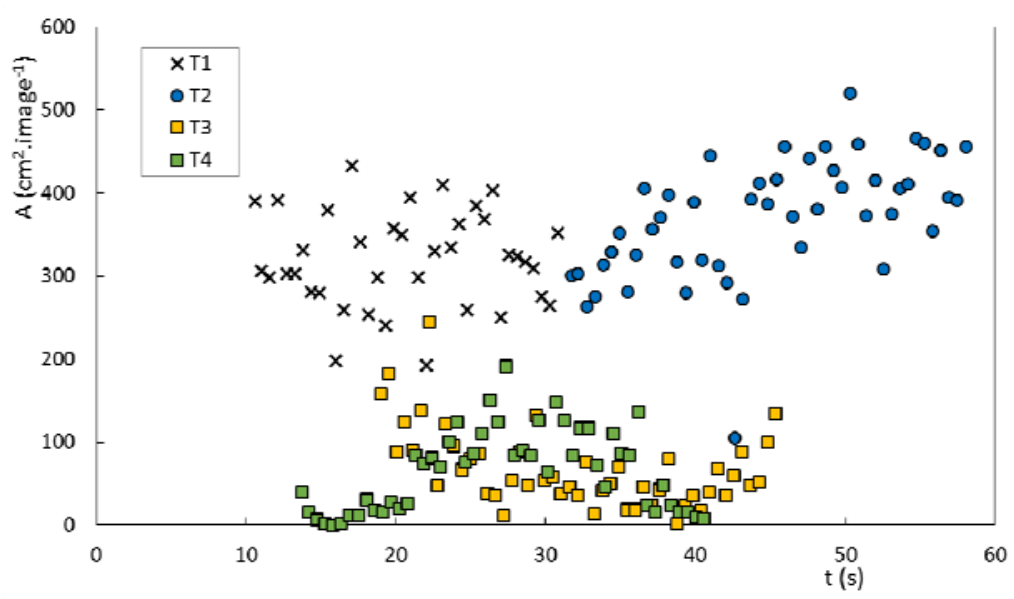

Figure 8. Total projected area of firebrands released during the burning captured by the PIV camera.

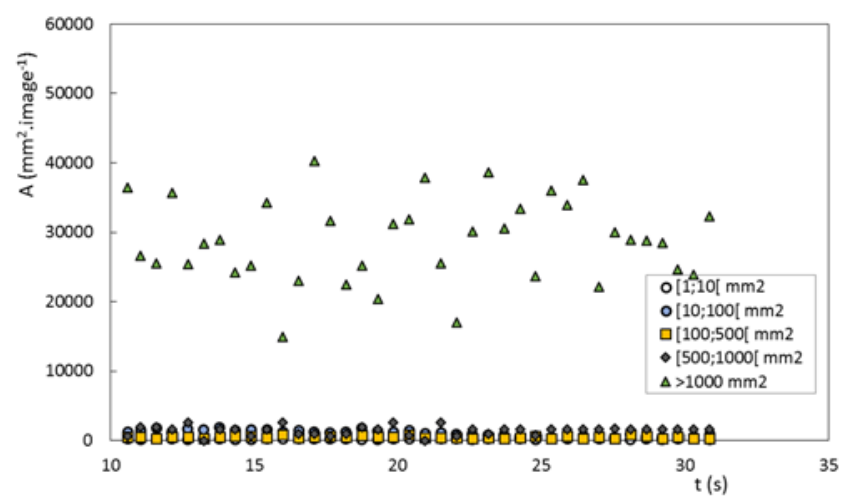

(a)

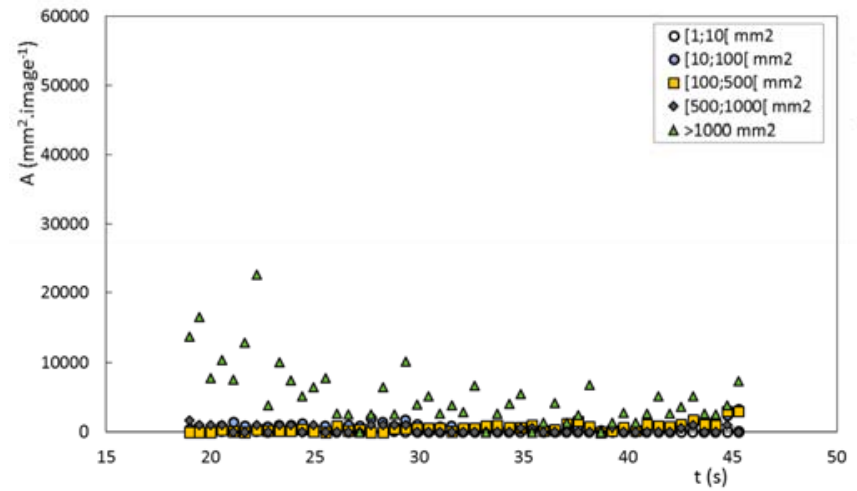

(c)

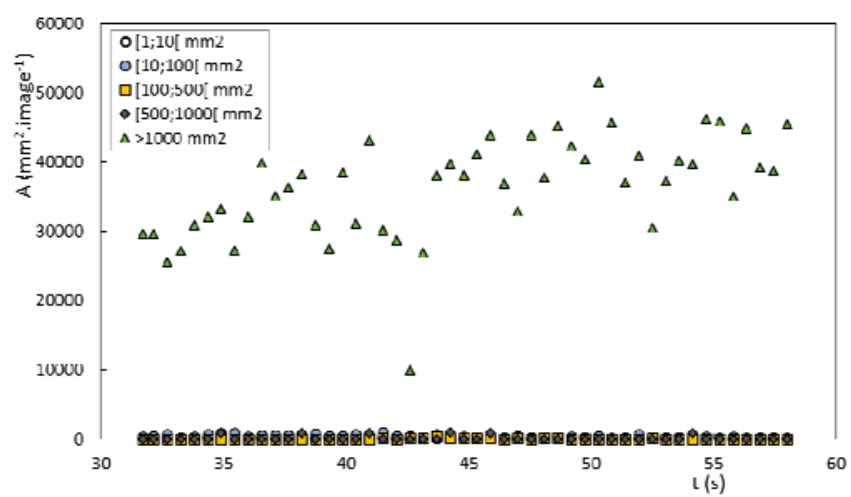

(b)

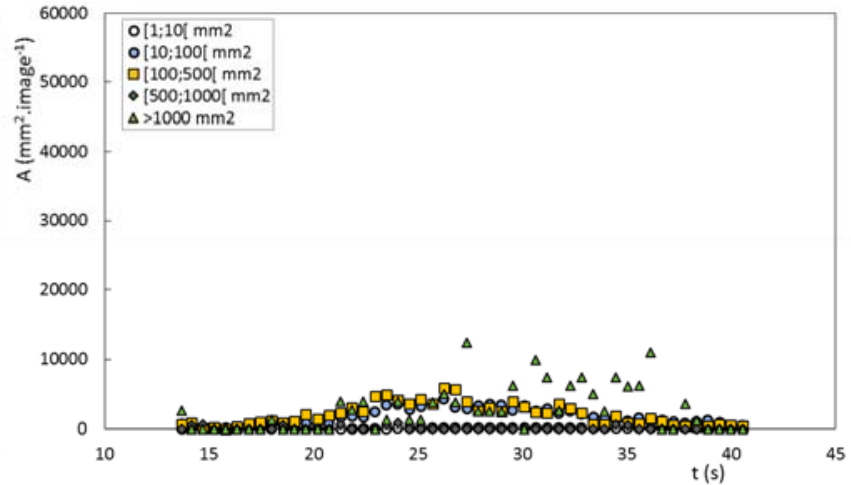

(d)

Figure 9. Area distribution of firebrands released during the burning captured by the PIV camera for T1 (a), T2 (b), T3 (c) and T4 (d).

Table 5. Values of average projected area of particles per PIV image.

\begin{tabular}{|c|c|c|c|c|}
\hline REFERENCE & T1 & T2 & T3 & T4 \\
\hline $\mathrm{A}_{\mathrm{av}}\left(\mathrm{cm}^{2}\right)$ & 320 & 370 & 69 & 65 \\
\hline
\end{tabular}

The four tests carried out are not sufficient to take ending conclusions on the relations among the parameters controlled. In addition the values of temperature and up flow velocity were not determined 
for T2. Nevertheless in Figure 10 the relation among the parameters is presented. As it would be expected, $T, V$ and $k$ vary in the same direction (Figure 10a, Figure $10 \mathrm{~b}$ and Figure 10c). Parameters $T$ and $V$ are very related as $V$ corresponds to the vertical convective flow that is induced by the heat of combustion. The number of particles released as function of the weight loss decay (Figure 10d) is not well defined however it is possible to see a tendency showing a decrease of $A_{a v}$ with rising of $k$ (Figure 10h). This is due to the more intense and complete burning of the fuels for larger values of $k$. A negative effect of $T$ and $V$ to $N$ and $A$ is also verified in Figure 10e, Figure 10f, Figure 10i and Figure 10j. It would be expected that larger values of $V$ would lead to an increase of $N$ and $V$ however, the larger values of $V$ are related to more complete burnings (larger $k$ and $T$ ) producing less particles. If to $V$ was added an induced airflow (wind for example) maybe the number and area of the particles would increase in the same direction. The relation $\mathrm{N}_{\mathrm{av}} v s \mathrm{~A}_{\mathrm{av}}$ (Figure $10 \mathrm{~g}$ ) is not well defined for the reasons previously explained.

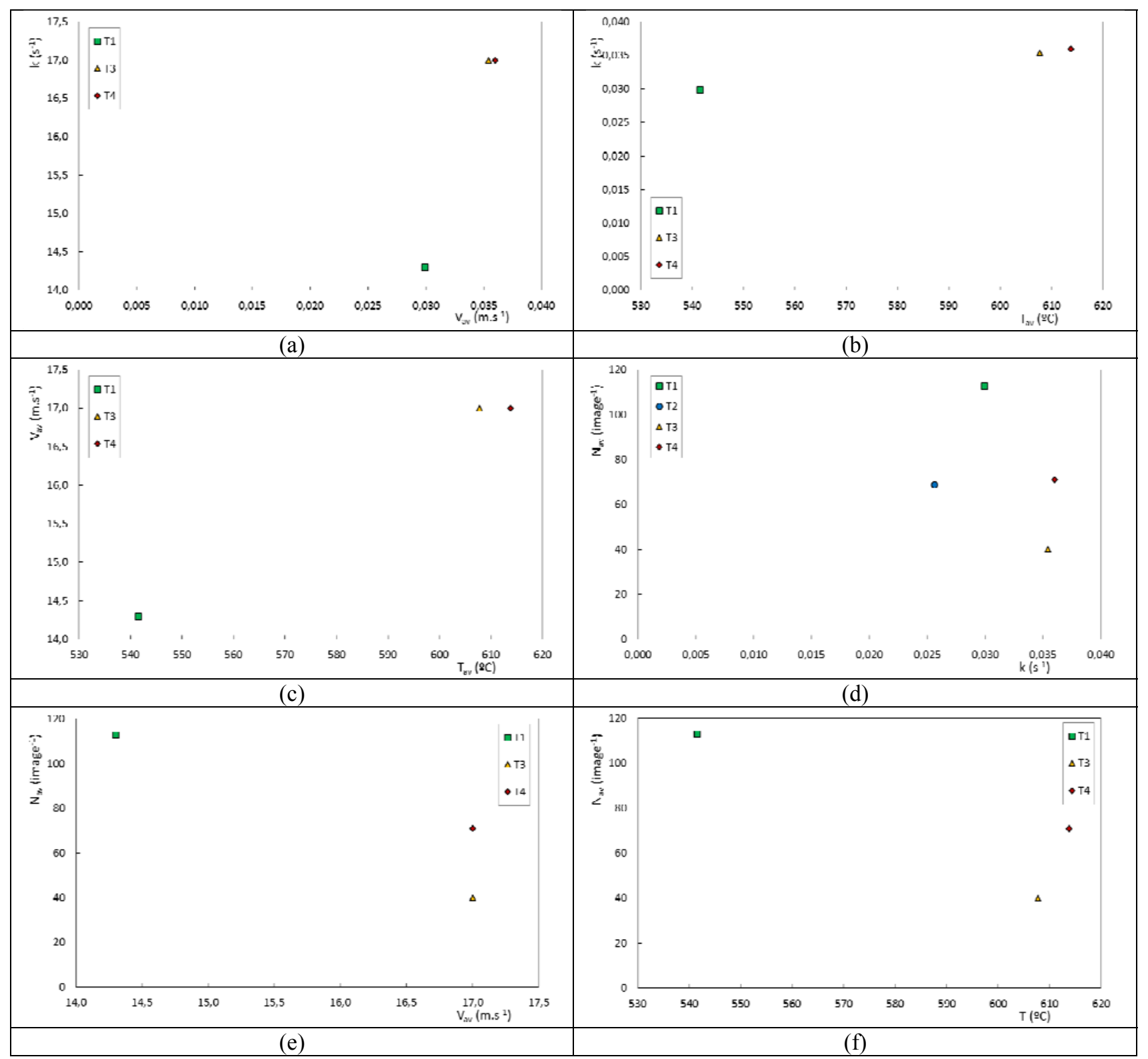




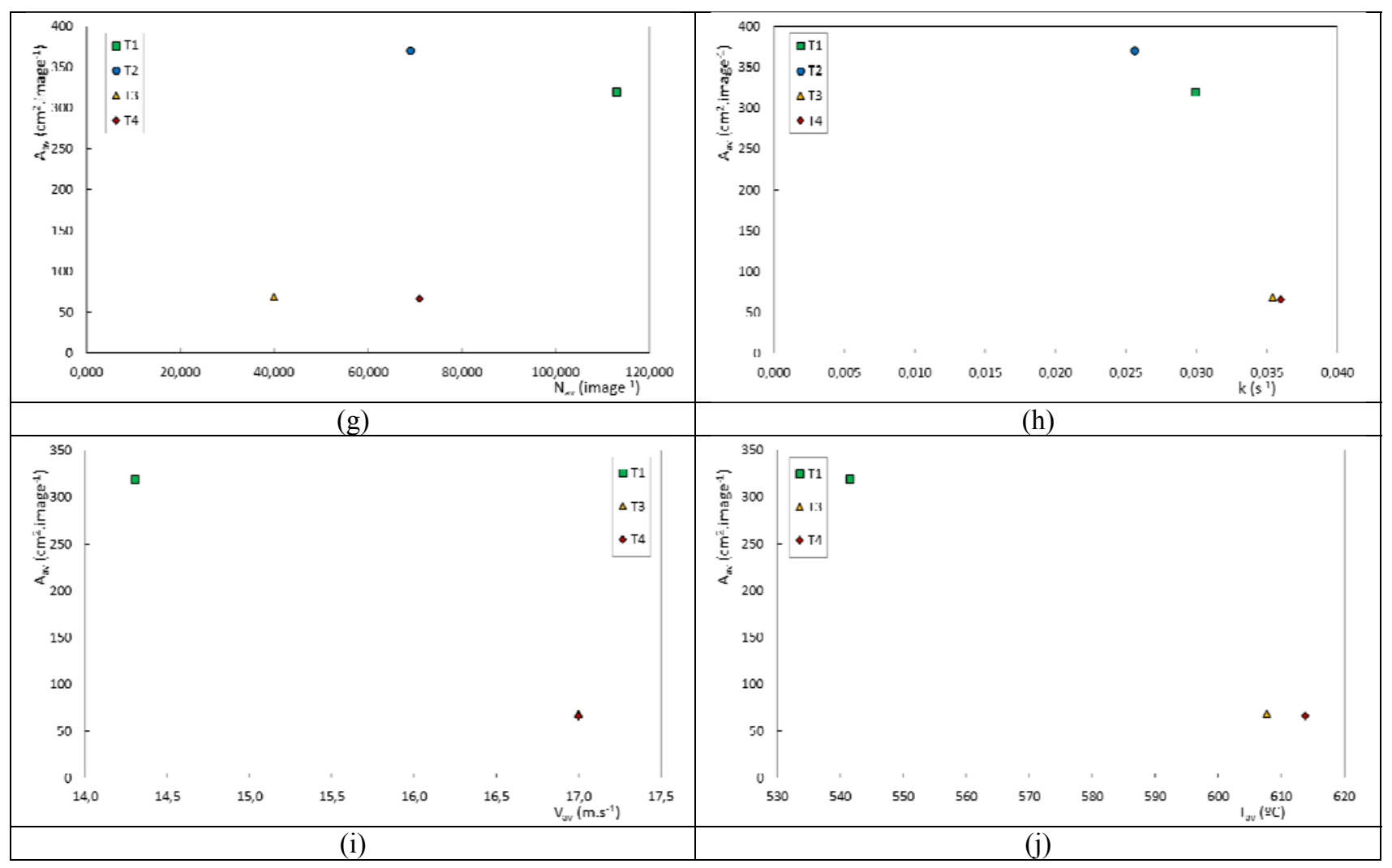

Figure 10. Relation between the parameters determined: (a) $k$ vs $V_{a v}$, b) $k$ vs $T_{a v}, A_{a v} v s k$, (c) $V_{a v} v s T_{a v}$, (d) $N_{a v} v s k$, (e) $N_{a v} v s V_{a v}$, (f) $\left.\left.N_{a v} v s T_{a v}, g\right) A_{a v} v s N_{a v}, h\right) A_{a v} v s k$, (i) $A_{a v} v s V_{a v}$, and (j) $A_{a v} v s T_{a v}$

\section{Conclusions}

Four burning tests were carried out in order to analyse the release of firebrands. Three of these tests burned shrubs and eucalyptus barks in different circumstances: 1) lay down of the shrubs fuel bed, 2) suspended in vertical position and 3) suspended in horizontal position. The fourth test consists of the burning of a singles fuel bed of shrubs.

The number and projected area of firebrands released, the weight loss decay, the temperature and the up flow velocity were determined. It was observed that burning shrubs with no barks (T1) working as obstacles produce many small particles below $100 \mathrm{~mm}^{2}$ (around $77 \%$ ) and particles larger than $1000 \mathrm{~m}^{2}$ (around 19\%). Test T2 produced mainly particles larger than $1000 \mathrm{~m}^{2}$ (around $41 \%$ ) as the less intense burning did not destroy the firebrands. Tests T3 and T4 produced mostly particles below $500 \mathrm{~mm}^{2}(89 \%$ and $97 \%$ respectively). Tests $T 3$ and $T 4$ were the tests with larger intensity and test $T 2$ was that with lower value of $k$ due to the muffling that the layer of barks produce in the shrubs fuel bed. There was not a clear difference between the results of T3 and T4 with different orientation of the barks. The values of $T, V$ and $k$ for both tests were very similar as well as the total project area of the firebrands. The distribution of the particles released was slightly different with $T 3$ releasing more particles larger than $1000 \mathrm{~m}^{2}$ and $T 4$ producing more particles in the range $\left[100 ; 500\left[\mathrm{~mm}^{2}\right.\right.$. Maybe the more narrow net of the barks in the horizontal position is a more effective obstacle to the larger particles. However, the larger particle released during the four tests was observed in T4 with $2852 \mathrm{~mm}^{2}$. These particles have potential to produce spot fires at short distance. We believe that induced wind during the burning would lead to the release of larger firebrands with capacity to produce spot fires at superior distances. The number and area of the firebrands released was analysed using one single PIV camera. This limitation may sometimes lead to a number of firebrands released inferior to the real number as some particles may be hidden behind one another. We do not consider this error as very relevant as it is 
would not be very frequent and eventual errors would be proportional to all the tests. The use of a second PIV camera capturing images in a perpendicular axis would avoid this fault and additionally would allow the determination of the velocity of firebrands which is much more accurate in a 3D analysis. The determination of the 3D shape of the firebrands would be possible with a second camera as well.

As future work we intend to extend the tests in number and carried out them for other scenarios with other fuels, introducing the induced wind as an additional parameter. The inclusion of a second PIV camera in order to avoid limitations and to analyse the velocity of firebrands is also foreseen.

\section{List of acronyms}

$\mathrm{A}\left[\mathrm{cm}^{2}\right.$ or $\left.\mathrm{mm}^{2}\right]$
$\mathrm{A}_{\mathrm{av}}\left[\mathrm{cm}^{2}\right.$ or $\left.\mathrm{mm}^{2}\right]$
$\mathrm{ADAI}$
$\mathrm{DB}$
$\mathrm{FMC}[\%]$
$\mathrm{H}[\mathrm{cm}]$
$\mathrm{K}\left[\mathrm{s}^{-1}\right]$
$\dot{m} \quad$
$\mathrm{~m}_{\mathrm{t}}[\mathrm{mg}]$
$\mathrm{m}_{0}[\mathrm{mg}]$
$\mathrm{N}$
$\mathrm{N}_{\mathrm{av}}$
$\mathrm{PIV}$
$\mathrm{r}^{2}$
$\mathrm{RH}[\%]$
$\mathrm{t}[\mathrm{s}]$
$\mathrm{T}\left[{ }^{\circ} \mathrm{C}\right]$
$\mathrm{T}_{\mathrm{av}}\left[{ }^{\circ} \mathrm{C}\right]$
$\mathrm{V}\left[\mathrm{m} . \mathrm{s}^{-1}\right]$
$\mathrm{V}_{\mathrm{av}}\left[\mathrm{m} . \mathrm{s}^{-1}\right]$
$\varnothing[\mathrm{cm}]$
$\Delta \mathrm{H}[\mathrm{cm}]$

Projected area of the particles released captured by the PIV system Average projected area of the particles released captured by the PIV system Associação para o Desenvolvimento da Aerodinâmica Industrial Dry basis

Fuel moisture content Tree height weight loss decay coefficient Relative weight loss decay

Mass at the instant $t$ Initial value of mass

Number of particles released captured by the PIV system Number of particles released captured by the PIV system Particle image velocimetry Correlation coefficient Relative humidity Elapsed time Temperature Average temperature Flow velocity Average flow velocity Tree canopy diameter

Distance from the surface fuel to the tree canopy base

\section{References}

Manzello SL, Maranghides A and Mell WE (2007) Firebrand generation from burning vegetation. International Journal of Wildland Fire, 2007, 16, 458-462.

Morandini F, Silvani X and Susset A (2012) Feasibility of particle image velocimetry in vegetative fire spread experiments. Experiments in Fluids, Volume 53, Issue 1, pp 237-244. DOI: 10.1007/s00348-012-1285-5.

Horváth I, Beeck J and Waterloo C (2012) Large-Scale Particle Image Velocimetry on a Full-Scale Pool Fire. 16th Int Symp on Applications of Laser Techniques to Fluid Mechanics Lisbon, Portugal, 09-12 July, 2012

Hosseini S, Li Q, Cocker D, Weise D, Miller A, Shrivastava M, Miller JW, Mahalingam S, Princevac $M$ and Jung $H$ (2010) Particle size distributions from laboratory-scale biomass fires using fast response instruments. Atmos. Chem. Phys., 10, 8065-8076, 2010 www.atmos-chemphys.net/10/8065/2010/ doi:10.5194/acp-10-8065-2010

McArthur, A. G. 1967. Fire behaviour in eucalypt forests. Comm. of Australia For. \& Timber Bur. Leaflet No. 107 
Ellis PF (2000) The aerodynamic and combustion characteristics of eucalypt bark - a firebrand study. Ph.D. Dissertation, Australian National University, Canberra.

Viegas DX, Almeida M, Raposo J, Oliveira R and Viegas CX (2012) Ignition of Mediterranean Fuel Beds by Several Types of Firebrands. Fire Technology. 2012 Springer Science + Business Media, LLC. DOI: 10.1007/s10694-012-0267-8.

Albini FA (1979) Spot fire distance from burning trees - a predictive model. USDA Forest Service, Research Paper INT-56, Intermountain Forest and Range Experiment Station 16.

Albini FA (1981) Spot fire distance from isolated sources - extensions of a predictive model. USDA Forest Service, Research Note INT-309, Intermountain Forest and Range Experiment Station 17.

Albini FA (1983a) Potential spotting distance from wind - driven surface fires. USDA Forest Service, Research Paper INT-309, Intermountain Forest and Range Experiment Station 18.

Albini FA (1983b) Transport of firebrands by line thermals. Combust Science Technology 32:27728819.

Sardoy N, Consalvi J, Porterie B, Fernandez-Pello A (2007) Modelling transport and combustion of firebrands from burning trees. Combust Flame 150:151-169.

Almeida M, Viegas DX, Miranda AI, Reva V (2011) Effect of particle orientation and of flow velocity on the combustibility of Pinus Pinaster Ait. and Eucalyptus Globulus Labill. firebrand material. International Journal of Wildland Fire 20(8):946-962.

Almeida M, Viegas DX, Miranda AI, Viegas C, Leitão N (2010) Aerodynamic Characteristics of Some Potential Embers. In: DX Viegas (ed) 6th international conference on forest fire research, Coimbra, Portugal, (CD-ROM). Associação para o Desenvolvimento da Aerodinâmica Industrial (ADAI), Coimbra, Portugal, 15-18 November 2010. 